\title{
НЕЗАЛЕЖНІСТЬ ПОЛЬЩІ У ВІЗІЇ НІМЦІВ ТА УКРАЇНЦІВ
}

\author{
ВойцєХ МОРАВСЬКИЙ \\ Варшавська школа економіки \\ Кафедра економічної та соціяльної історії \\ проспект Незалежності, 162, 02-554 Варшава, Польща \\ e-mail:wmoraw@sgh.waw.pl
}

Друга Річ Посполита була багатонаціональною державою. Однак, влада не вирішила сформувати федерації, прагнула більше чи менше завуальовано асимілювати національні меншості. 3 перспективи часу і реалій належить визнати, що це було неможливо реалізувати. В міжвоєнній Польщі ключову роль відігравали відносини поляків 3 двома меншостями: німцями й українцями. Обидві нації опинилися в межах Другої Речі Посполитої після програшу у війнах й трактували свій стан в найкращому випадку за тимчасове необхідне зло. Шанси на політичну стабілізацію сформованої таким робом держави були мінімальні.

Ключові слова: німці, українці, Друга Річ Посполита, асиміляція.

\section{Загальна перспектива}

У 1974 р. я навчався на першому році історичного факультету Варшавського університету й слухав лекції професора Александра Гейштора. Професор ознайомив нас з історичними концепціями Фернана Броделя. Один із провідників “школи Анналів" виокремлював в історичному процесі три, значною мірою автономні хронологічні періоди: час короткої тривалости (подій), час середньої тривалости (циклічний, час кон'юнктури) і час довгої тривалости ${ }^{1}$. Професор А. Гейштор проілюстрував це прикладом, який мені запам'ятався. Говорив приблизно так: "У час між двома світовими війнами ще не знали концепцій Броделя, але ми якимось робом вже мислили його категоріями. Ми, молоді люди, виховані у вільній Польщі, вважали за очевидне, що здобуття незалежности є явищем 3 природою довготривалим. Тим часом з'ясувалося, що до цього спричинилася лише кон'юнктура". Така оцінка мені постійно пригадувалася, коли зустрічався з визначенням Другої Речі Посполитої як “сезонної держави”. 3 одного боку, я відчув природній рефлекс, що спонукав відкинути таке визначення. Воно підозріло резонувало і з антипольською пропагандою міжвоєнної Німеччини, і з відомим виступом В'ячеслава Молотова 1939 р. 3 іншого боку, правдивими були і слова професора Гейштора, передовсім тому, що національна структура Другої Речі Посполитої грунтувалася на нестійкій рівновазі сил, яка не могла утримуватися надто довго.

Досліджувати цю історичну проблему мене спонукала т. зв. історична політика, яка в Польщі, очевидно, опинилася у глухому куті. Історична політика

\footnotetext{
${ }^{1}$ Детальніше див: Fernand Braudel, Historia i trwanie. (Warszawa: Czytelnik, 1999). 
буде ефективною, коли нашу історичну наррацію розумітимуть і визнаватимуть рівноправною інші суб'єкти історії. Рівноправною, але не єдиною. Таке визнання можливе лише на засаді взаємности, а іiі не можливо досягти без емпатії. Перефразовуючи відомі слова єпископів 1965 р., девізом таких завдань може бути: “стараємося зрозуміти і просимо розуміння". Тут мушу застерегти, що “зрозуміти” не завжди означає “визнати правдивість”. Це також не обов”язково означає “пробачити”. Однак, ніхто мене не переконає, що краще не розуміти, ніж розуміти. 3 цих причин варто прийняти плюралізм наррації, а погляд на польські справи з точки зору національних меншостей, що мешкають в нашій країні, може лише розширити наші горизонти. Відкритість колись була стандартом, зараз іiї необхідно боронити від націоналістичної наррації, яка виключає “чужі” елементи.

XIX століття було часом розвитку націотворчих процесів і зростання значущости національної свідомости. Це підкопувало багатонаціональні держави, що домінували в Центрально-Східній Европі. Коли в Західній Европі держави набули національного характеру $^{2}$ ще в нові часи (якщо не раніше), то в нашій частині континенту довго домінували багатонаціональні монархії, колись створені в результаті завоювань чи династичних союзів. Більшість націй в цій частині Европи не мали власних держав. За таких обставин національна свідомість вибудовувалася, грунтуючись на етнічній спільності чи, передовсім, на спільній мові.

Поляки тут не були особливі. Після поділів Речі Посполитої польська національна свідомість розвивалася двома шляхами. Поляки в XIX ст. не мали своєї держави, але втратили її відносно недавно. Пам'ять про форму цієї держави, в т. ч. й територіяльну, була настільки свіжа, що на неї могли покликатися. Зберігався державний, політичний патріотизм. Патріоти від часу національних повстань боролися за відбудову такої Польщі, яка колись існувала в кордонах 1772 р. Це означало воювати за відродження багатонаціональної держави, що помітно й у символіці повстань. Під час листопадового повстання вживано герб 3 двох частин, на якому був Орел і Погонь. Це була традиційна візія Речі Посполитої двох народів: поляків і литовців. У січневому повстанні використовували трикуспідальний щит з Орлом, Погоню й Архангелом Михаїлом (символом Русі). Тут бачимо візію Речі Посполитої трьох народів: поляків, литовців та українців. У будь-якому випадку Польщу не вважали етнічно однорідною державою. У 20 -х роках XIX ст. національна демократія запропонувала етнічне розуміння нації. Її метою була Польща як мононаціональна держава. Не випадково ендеки були першим політичним рухом в Польщі після поділів, який відкидав ідею багатонаціональної держави․․ Це також означало

\footnotetext{
${ }^{2}$ Навіть, Швайцарії з ії етнічним, в будь-якому разі мовним різноманіттям, вдалося витворити почуття національної ідентичности, яке грунтувалося на державному патріотизмі.

${ }^{3}$ Добре ілюструє оригінальність ендеків під цим кутом зору приклад з протилежного боку політичного спектру. Соціял-демократія Польського Королівства і Литви при всьому своєму небажанні незалежности, виявилася у виборі назви напрочуд консервативною - Соціял-демократія Обидвох Народів (як перед поділами).
} 
ISSN 2078-6077. Наукові зошити історичного факультету Львівського університету. 2020. Випуск 21. Proceedings of History Faculty of Lviv University. 2020. Issue 21.

відмовитися від традиційного територіяльного визначення, чи кордонів 1772 p. Ендеки, на відміну від традиційних патріотів, головною вважали етнічну спільноту, а не політичну. Так вони змінили основні геополітичні параметри польського питання. Для польських патріотів найбільшим нещастям була втрата держави чи втрата незалежности. Саме тому для них головним ворогом була Росія. Вона відіграла провідну роль у поділах, бо Росія відібрала більшість території давньої Речі Посполитої зі столицею. На біду, можна було б уявити незалежну Польщу без Галичини чи прусської частини, але не без Варшави. Для націоналістів це виглядало інакше. Якщо головною цінністю став народ, а не держава, то втрата незалежности перестає бути найбільшим нещастям. Вона була лише втратою держави. Коли народ переживе цей виклик, то колись собі незалежність відшукає. Справжньою бідою була б денаціоналізація чи втрата національної свідомости. Нація, яка дозволить собі денаціоналізацію, перестає існувати. Націоналісти вірили, що це можливо. За такого підходу національну приналежність людини остаточно визначає іiї власна свідомість. Інакше кажучи, людина $є$ тим, за кого себе вважає. Оскільки так, то можна ії переконати змінити своє бачення. Якщо переконаємо поляка, що він $є$, наприклад, німцем настільки успішно, що сам добровільно про це говоритиме, то від тієї хвилі буде німцем і неможливо з цим дискутувати.

Потрібно пам'ятати, що зміна національної свідомости може бути лише добровільним актом. Силою тут нічому не зарадиш. А оскільки так, то нація, яку асимілюють, мусить бути настільки привабливою, щоб було “варто” іiі денаціоналізувати. Інакше кажучи, мусить чимось вражати, а сама асиміляція повинна пов'язуватися із поступом, що відчутий суб'єктивно. 3 цього погляду різні національні культури не $є$ рівнозначні. Вони $€$ ієрархізовані щодо рівня привабливости. Одні більше придатні до денаціоналізації, інші - менше. Рух в протилежному напрямку є мало правдоподібний.

Дивлячись 3 цієї перспективи на країни, які поділили Польщу, ендеки наново оцінили їх можливості і визнали, що при всій своїй брутальності росіяни не $\epsilon$ небезпечними, бо зросійщити поляків їм не вдасться. Простіше кажучи, вважали російську культуру замало привабливою, щоб вона заімпонувала полякам. 3 німцями справа виглядала небезпечніше. Якщо німці будуть діяти мудро і не робитимуть багато помилок, то германізація поляків може їм вдатися. Саме тому, обираючи між німцями і росіянами, поляки повинні йти з росіянами, бо німці є найнебезпечнішою нацією серед тих, хто поділив Польщу. Зауважмо, що в цьому міркуванні було щось 3 поваги до німців й дещо із зневаги до росіян. Ефектом, однак, було посилення проросійської орієнтації.

Також варто звернути увагу, що подібні критерії, як при оцінці можливости денаціоналізації поляків, ендеки ідею шансу полонізувати національні меншості, які замешкували Польщу. Вірили в можливість полонізації литовців, білорусів та українців. При цьому національну свідомість українців вважали розвинутішою, ніж білорусів. Саме тому т. зв. лінія Дмовського, чи пропонована під час мирних 
переговорів у Парижі в 1918 р. візія кордонів Польщі на півночі, на білоруському відтинку була висунута на схід істотно далі, ніж на південному відтинку українському.

Націоналістична формула національної свідомости, пристосована до польськонімецької конфронтації на Заході, виявилася абсолютно непридатною до відносин на Сході. Там (у будь-якому випадку, поки ситуація не сприймалася як придушення прагнень національних меншостей, а лише як польсько-російське протистояння) потрібна була формула багатонаціональної держави, де б шанували ідентичність й свободу вибору. За такими принципами спробував будувати польську східну політику Юзеф Пілсудський, але прихильність до цього в польському суспільстві постійно зменшувалася. Про це свідчили падіння федеральної політики, поразка Центральної Литви, а пізніше ескалація польськоукраїнського конфлікту.

Друга Річ Посполита, чи, власне, відроджена Польща з'явилася з плутанини після Першої світової війни як багатонаціональна держава. Відомі суперечки істориків щодо неточности даних, які грунтуються на переписі людности від 1931 p. ${ }^{4}$ Долучимо остаточні підрахунки Сжи Томашевського, які вважаємо виваженими і близькими до реальности. За ними, поляки складали $65 \%$ громадян Речі Посполитої, українці - 16\%, євреї- $10 \%$, білоруси - $6 \%$, німці - $2 \%$, інші $1 \%{ }^{5}$. Реальне значення взаємин з конкретними меншинами не відображало їхній чисельний потенціял й залежало радше від того, як ці відносини могли вплинути на довговічність держави. Зваживши на це, можна збудувати іншу ієрархію важливости. Польсько-єврейські відносини були важливі з огляду на їх вплив на зовнішню політику. Поступово зростало значення євреїв у формуванні образу Польщі в світі. Проте, не від них залежало виживання Другої Речі Посполитої. Тим паче, воно не залежало від ставлення до відродженої Польщі білорусів, росіян, татар чи литовців. Життєво важливими для Польщі були взаємини з двома націями: німцями й українцями.

Можна стверджувати, що справи в взаєминах у трикутнику німці-полякиукраїнці визначали результат експерименту, за яким була створена багатонаціональна Друга Річ Посполита. Ризикнемо висунути тезу, що у польськонімецьких й польсько-українських взаєминах можна говорити про щось на зразок симетрії. Коли під кінець Першої світової війни за пунктами президента Вільсона право націй до самовизначення піднесли до ранги фундаменту міжнародних відносин, слідом за цим не прийшло визнання рівности націй. Навпаки, продовжував домінувати погляд, що деякі нації є важливіші від інших й мають виконати щодо них цивілізаційну місію. Порівняння формального прийняття націоналізму з толерантністю щодо їх ієрархії й оцінки створило сприятливий

\footnotetext{
${ }^{4}$ Див.: Jerzy Tomaszewski, Ojczyzna nie tylko Polaków. (Warszawa: Młodzieżowa Agencja Wydawnicza, 1985), s. 31-51.

${ }^{5}$ Ibidem, s. 50.
} 
ISSN 2078-6077. Наукові зошити історичного факультету Львівського університету. 2020. Випуск 21. Proceedings of History Faculty of Lviv University. 2020. Issue 21.

грунт для злих емоцій, які в результаті зробили версальський лад лише коротким епізодом між двома світовими війнами.

Міжвоєнна Польща була багатонаціональною державою, яка не вирішила мати федеративний устрій, а прагнула в більше чи менше завуальований спосіб асимілювати меншини. Мало це низку наслідків. Одним з найсерйозніших була корозія демократії. Збереження національного характеру багатонаціональної держави мало актуалізувати питання рівности громадян перед законом та легітимности демократичних механізмів. Драматично це дало про себе знати під час виборів 1922 р. й президентства Габриеля Нарутовича. Прив'язаність до демократичних механізмів обидвох політичних таборів Другої Речі Посполитої виявилася поверховою. Табір лівих незалежників, на який у 1926 p. політично опирався Юзеф Пілсудський у часи Першої світової війни, отримав досвід меншости, яка (на ії̈ власну думку) мала рацію проти думки більшости. Болючою травмою для того середовища стало вбивство президента Г. Нарутовича.

Ставлення Національної Демократії до демократії, написаної з малої літери, вимагає ретельнішого аналізу. Цей рух помістив слово “демократія” в своїй назві на сам кінець. Було воно для націонал-демократів важливе. Як вони розуміли це слово? Видається, що для ендеків “демократія” мала два визначення. По перше, воно відображало соціяльний егалітаризм у національній спільноті, відмову від будь-яких пережитків станових поділів. По друге, ендеки специфічно розуміли демократичні механізми. В “Думках сучасного поляка" читаємо: "Бути поляком - означає, що належиш до польської нації на всій ії території і за весь час іiї існування. Це означає, що відчуваєш свій тяглий зв'язок з цілою Польщею, і нинішньою (...), і минулою (...), i, врешті, майбутньою (...). Щодо сучасної Польщі людина відчуває обов'язок від свого імени, а до давнішої і майбутньої -

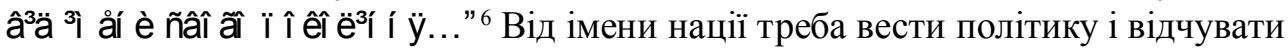
себе відповідальним перед нею. Якщо дослівно, а не риторично, трактувати таке формулювання, то це спричинить серйозні наслідки для устрою держави. При такому визначенні нації покоління, що зараз живе, є лише випадковою меншістю і може повністю помилятися. Його думка не мусить бути обов'язкова для лідера, який відповідає перед спільнотою, яка розуміється широко і “знає краще"7.

Зваживши історичний досвід, асиміляцію меншин варто визнати нереальним завданням. І німці, й українці опинилися в межах Польщі після того як програли війни і трактували свій стан в кращому випадку як перехідне необхідне зло. При цьому німці вважали себе нацією цивілізованішою від поляків й з презирством

\footnotetext{
${ }^{6}$ Roman Dmowski, Myśli nowoczesnego Polaka. (Gdańsk: Młoda Polska, 1981), 17-18.

${ }^{7}$ Обмеженням демократизму ендеків було також ексклюзивне розуміння нації, звуження іiі до римо-католицизму та сектантське виокремлення “Правильних Поляків”. Проти елементарної логіки, це посилювалося в моменти тріюмфу. Це сприяло успішності ендеків в опозиції, їх слабкости й нетривалости в урядуванні.
} 
дивилися, наприклад, на польську економіку (Polnische Wirtschaft). Поляки своєю чергою подібно трактували українців (порівнюємо тут очевидно те, що відбувалося до 1939 р., а не перекручення Другої світової війни). Вони ставили під сумнів саме існування української нації й вірили в можливість полонізації українців. При цьому поляки вважали, що германізація їх самих не має шансу, а полонізація українців може відбутися. Саме тут на перший план вийшла національна мегаломанія, яка, як відомо, не минуче йде в ногу з прихованими комплексами ${ }^{8}$.

\section{Німці}

Ставлення німців до Другої Речі Посполитої було виразно вороже. В німецькій східній традиції зіткнулися дві політичні концепції. За однією, символом якої був Отто Бісмарк, східним сусідом Німеччини є Росія, з якою необхідно жити мирно й разом контролювати багато менших народів, що мешкали між німецькою й російською етнічними територіями. За другою, Росія є небезпечним сусідом, перед яким Німеччина може захиститися, підтримуючи прагнення націй, що жили між нею і Росією. Формування на цих землях незалежних держав звільнить Німеччину від російського сусідства. Такий спосіб мислення актуалізувався під час Першої світової війни в проєкті Центральної Европи (Mitteleuropa), на ньому також грунтувалася підтримка 3 боку Німеччини окремих польських прагнень й акту 5 листопада. Після капітуляції у 1918 р. на короткий час німці помірковано прихильно поставилися до незалежної Польщі. Німеччина швидко визнала польську державу й вела предметні переговори про евакуацію Польщею відділень Ober-Ost. Все змінилося після великопольського повстання, а пізніше участи Польщі як члена Антанти у мирних переговорах. Зауважмо, що територіяльні втрати Німеччини на користь Польщі були найбільші з усіх, які німці понесли в результаті версальського договору. Коли втрати на користь Франції і Бельгії були наслідком військової поразки в запеклих боях, то німці не мали враження, що їх перемогли поляки. На думку німців, поляки були невдячним народом, який швидко забув про роль німців в отриманні польської незалежности. Німці закидали полякам, що вони в час слабкости Німеччини приєдналися до іiі ворогів і максимально з цього скористалися. При цьому розміри польських територіяльних прагнень здивували німецьку громадську думку.

3 такого погляду ставлення до конкретних фрагментів нового кордону відрізнялося. Хоч німці у Великопольщі почувалися як у себе, однак розуміли, що в цій провінції мешкає польська більшість. Коли Польща отримає незалежність, а Німеччина в той самий час програє війну, то не вдасться утримати Великопольщу. Звичайно, думали про це без ентузіязму, але якась частина німецької громадської думки (очевидно, менша) була готова погодитися на такий розв'язок.

\footnotetext{
${ }^{8}$ Пропоную читачам прийняти такий спосіб міркування, який мені також дозволяє багато зрозуміти у взаєминах між цими трьома народами. Коли маю проблеми із розумінням, чому українці так, а не інакше реагують на польські кроки, то уявляю собі як би поляки зреагували на аналогічні вчинки німців. Зазвичай, в цей момент все мені стає зрозуміло.
} 
ISSN 2078-6077. Наукові зошити історичного факультету Львівського університету. 2020. Випуск 21. Proceedings of History Faculty of Lviv University. 2020. Issue 21.

Несподіванішою стала поява проблеми польського Помор'я й доступу Польщі до моря. Німці менше розуміли право Польщі на ці землі. Разом з тим, таке вирішення мало набагато серйозніші практичні наслідки. Це означало перетнути територію Німеччини і відокремити анклав Східної Пруссії. Попри те, частина німецької громадської думки, звичайно істотно менша, ніж у випадку 3 Великопольщею, була схильна бачити цю проблему в категоріях відплати за поділи давньої Речі Посполитої.

Навіть небагато дружніх до Польщі німців не могли зрозуміти, чому з'явилася проблема Верхньої Сілезії. Цього неможливо було усвідомити, навіть в категоріях компенсації за кривди поділів. Сілезія не була анексована, бо вже раніше не належала до Польщі.

Все це призвело до того, що жодна держава не пробуджувала в міжвоєнній Німеччині таких негативних емоцій, як Польща. Перед 1933 р. польсько-німецькі відносини були фатальні, що повністю відповідало очікуванням німецької громадської думки. Жоден уряд Ваймарської республіки не міг (навіть, якби хотів) покращити взаємини з Польщею. Уряд, який би щось таке зробив, з цієї причини би впав. Стан справ змінився після приходу до влади Гітлера.

Значення німців у Другій Речі Посполитій визначала не їх чисельність, але факт, що за ними стояла потуга сусідньої держави, що з будь-якого погляду (крім, тимчасово військового потенціялу) насувалася над Польщею. Німці в Другій Речі Посполитій з огляду на їх минуле належали до трьох груп. Найчисленнішу першу групу складали ті, що раніше були громадянами Райху. Замешкували вони Великопольщу, Помор'я й частину сілезького воєводства. Для цієї групи зміна кордонів після Першої світової війни була найдраматичнішою. 3 правлячої нації, яка замешкувала власну державу, вони стали національною меншістю. Що гірше, зараз урядувала нація, яку донедавна вони самі пригноблювали і намагалися германізувати. За таких обставин могли очікувати відповіді. Представники цієї групи були піддатливі до націоналістичних гасел й схильні трактувати відроджену Польщу як перехідний витвір.

Другу групу складали ті, хто перед 1914 р. жили в Польськім королівстві чи на Східних кресах. Для них зміна не була така драматична. Ще раніше вони були національною меншістю. Зараз змінилася лише держава, в якій їм довелося жити. Вони були краще пристосовані до нової ситуації й готові прийняти новий порядок.

Третю групу складали німці, які колись замешкували Галичину і Цєшинську Сілезію. Німці в Галичині швидко асимілювалися і з ними не було проблем. Трохи інакше було з німцями в австрійській Сілезії. Вони подібно до колишніх громадян Райху відчували втрату позицій панівного народу й перетворення на національну меншість. Також були піддатливі до впливів національної ідеології, але радше у версії етнічній ${ }^{9}$, а не націоналістичній. Не випадково у 1930-х рр. бєльські німці найбільше піддалися національному соціялізмові.

9 В німецькій мові вже в ХІХ ст. функціонували два терміни, які визначали націю в дещо різному розумінні: Volk i Nation. Nation означав політичну націю - громадян Райху. Volk означав німців в етнічному значенні; тих, що розмовляють німецькою. На випадок 3 німцями тут була 
Німці в Польщі охоронялися т. зв. малим версальським договором ${ }^{10}$. Подібні угоди мусіли підписати всі держави, які отримали нові території в результаті конференції. Німці, які втратили землі, не мусіли виконувати подібних зобов'язань. Це створило асиметрію, яку усунули лише після нормалізації польсько-німецьких відносин в 1930-х рр.

Німці, що опинилися в Польщі, перед зовнішніми викликами об'єднувалися в свої національні, позапартійні й кооперативні організації. Всередині цих інституцій існували різні погляди, однак це трактували як внутрішні справи, що не повинні демонструватися чужому й неприхильному оточенню. Так само в попередню епоху себе поводили поляки в Німеччині. 3 часом за територіяльним принципом сформувалися три німецькі національні організації ${ }^{11}$ : Німецька Асоціяція (Deutsche Vereinigung) на землях, які входили до складу Пруссії, Німецький Народний Союз (Deutscher Volksbund) - у Сілезії і Німецька Народна Асоціяція (Deutsche Volksverband) - на решті території Польщі. Організовано також партії не за національним принципом, а лише ідеологічним: Німецька Католицька Народна Партія (Deutsche Katholische Volkspartei; з часом перетворена в Німецьку Християнську Народну Партію (Deutsche Christianische Volkspartei) чи Німецька Соціялістична Робітнича Партія (Deutsche Sozialistische Arbeitrspartei), але вони менше значили.

Німці, крім охорони трактатом своїх прав як меншість, мали гарантоване право вибору - залишитися в Польщі. При цьому їх матеріяльні інтереси були повністю захищені. Питання залишитися і жити на постерунку чи переїхати до Німеччини було не однозначне. Опція репатріяції фактично означала погодитися з територіяльними змінами. Ті, хто вирішив переїхати, послаблювали політичний потенціял й силу впливу тих, які залишалися. Подібну дилему переживали поляки на Східних кресах одразу ж після війни чи угорці в Семигороді після трактату в

істотна різниця. До Volk зараховували, наприклад, австрійців, більшість швайцарців, які не належали до Nation. Відповідно до цього німецький правий рух поділився на націоналістичний та етнічний. Між ними була істотна різниця. Після 1919 р. для німецьких націоналістів першочерговим завданням було відновлення кордонів 1914 р. В цьому місці німецька держава зазнала втрат й це варто виправити. Для німецького етнічного правого руху головним завданням було об’єднати усіх німців в єдиній державі. Лише відбудова Райху в кордонах 1914 р. цього не забезпечувала. Звідси й інші напрями експансії. Для німців першої групи реалізація націоналістичної програми означала реалізувати свої прагнення. Для бєльських німців цього було замало. Для їх з’єднання з Райхом була необхідна етнічна програма. Детальніше див.: George L. Mosse, Kryzys ideologii niemieckiej. Rodowód intelektualny Trzeciej Rzeszy. (Warszawa: Czytelnik, 1972).

${ }^{10}$ Договір між головними союзними державами і Польщею від 28 червня 1919 р., названий “малим версальським договором” накладав на Польщу обов' язок забезпечити права національних меншин. Див.: Por. Władysław Józef Zaleski, Międzynarodowa ochrona mniejszości narodowych. (Warszawa: St. Niemiry Syn i S-ka, 1932).

${ }^{11}$ Про німецькі політичні партії в Польщі див.: Jerzy Holzer, Mozaika polityczna Drugiej Rzeczypospolitej. (Warszawa: Ksi|ka i Wiedza, 1974), 274-284, 580-594; Karol Grünberg, Niemcy i ich organizacje w Polsce mi'dzywojennej. (Warszawa: Wiedza Powszechna, 1970). 
ISSN 2078-6077. Наукові зошити історичного факультету Львівського університету. 2020. Випуск 21. Proceedings of History Faculty of Lviv University. 2020. Issue 21.

Тріаноні. В результаті число німців у міжвоєнній Польщі зменшилося від майже 1 млн. в 1921 р. до 0,7 млн. в 1931 р. У специфічній соціяльній структурі німців у Польщі, де найбільше було великої земельної власности, дражливим питанням була земельна реформа. Після 1925 р. існувала спокуса, щоб примусовим “допарцелюванням” польська держава особливо вдарила по німецьких маєтках. Таку небезпеку помітила Ліга Націй і пильнувала за цією справою.

Для німців стати національною меншістю в краю, де вони панували, було неприйнятним. Польська влада могла сподіватися на мінімальну (і то не завжди) державну лояльність. Шанс на неї тимчасово зріс після укладення пакту про ненапад в 1934 р., але це був максимум того, чого можна було успішно вимагати від німців. Пам'ятаймо також, що німецькі й господарські (наприклад, розбудована кооперація), й культурні (наприклад, шкільництво) організації отримували майже необмежені фінанси від німецької держави. Згода німецької меншости зі своїм статусом в Польщі не могла довго тривати за умов наростання скрізь націоналізму.

\section{Українці}

Українці опинилися у Другій Речі Посполитій після програного національного повстання ${ }^{12}$ й 3 почуттям, що їх країна окупована. Поляки дотепер так визначають стан справ у Східній Галичині. Тоді ж вважали всю Галичину за свій край і частину давньої Речі Посполитої, яку окупувала Австрія. Були переконані, що оволодіння цілою Галичиною було інтегральною частиною акту історичної справедливости, виправленням кривди поділів. Очевидно, поляки розуміли, що Галичина є етнічно різна, але переконані, що існують реальні шанси полонізувати українців. Це була дуже небезпечна і наївна ілюзія, однак настільки поширена, що їі варто проаналізувати. І тому:

По перше, поляки вважали, що здобуття незалежности означає повернути всі історичні можливості, які мала давня Річ Посполита і які змарновано в результаті власних політичних помилок. Річ Посполита в XVI і в першій половині XVII ст. мала (хоч про це можна дискутувати) шанс на створення понадетнічної і понадрелігійної політичної спільноти у вигляді “політичної нації”. Проте, через істотні політичні помилки, про які тут не варто детально вести мову, вона ті шанси змарнувала. Починаючи, щонайменше від 1648 p. ті можливості вже відійшли у минуле. Шанси побудувати “державницьку” національну свідомість, засновану на почутті політичної спільноти, були в конкретний час ${ }^{13}$. Оскільки

\footnotetext{
${ }^{12}$ Історію конфлікту з українського погляду див.: Василь Кучабський, Західна Украӥна у боротьбі з Польщею та більшовизмом у 1918-1923 роках. (Львів: Дослідно-видавничий центр Наукового товариства ім. Шевченка, 2015); Павло-Роберт Магочій, Ілюстрована історія Украӥни. (Київ: Критика, 2012); Vasyl Kuchabsky, Western Ukraine in Conflikt with Poland and Bolshevism 1918-1923. (Edmonton-Toronto: Canadian Institute of Ukrainian Studies Press, 2009); Paul Robert Magosci, Historia Ukrainy. Ziemie i ludzie. (Krakyw: Ksikgarnia Akademicka, 2017), 697 and next.

${ }_{13}$ Таким робом в певний час вдалося створити французьку націю. Чи вдалося створити британську чи іспанську націю, то в світлі нинішніх подій, дуже дискусійно.
} 
вже змарновані, то марно сподіватися їх повернути. Після поділів Польщі розвинулася українська національна свідомість і це був вже процес безповоротній. Вже не було жодних можливостей його перезавантажити. Ендеки собі вигадали, що є шанси полонізувати слов'янські національні меншості, накидаючи таке мислення більшості поляків. Звідси тенденція заперечити українську національну ідентичність й термін “етнографічний матеріял”, що вживався до слов'янських національних меншостей.

По друге, поляки спрощено дивилися на події 1918-1921рр. Так, воювали 3 українцями за Східну Галичину, але пізніше був союз з Петлюрою, київська експедиція, братерство зброї і, насамкінець, зворушливе вибачення, з яким Юзеф Пілсудський звернувся до українців. Саме тому баланс взаємин не $є$ однозначно негативний і можливі різноманітні компроміси. Слабкість такого розуміння полягала, однак, в незнанні внутрішніх розбіжностей в українській нації. Воно не враховувало, що в 1918-1919 pр. поляки воювали з галицькими українцями, а союз і братерство зброї мали з наддніпрянцями. Для галицьких українців досвід Петлюри і київська експедиція були чужими. Що гірше, мали право закидати Петлюрі те, що погодився залишити їх по польськім боці кордону, що вважали зрадою ${ }^{14}$. А в кордонах Другої Речі Посполитої опинилися власне галицькі українці. Також там замешкували і волиняни, але галичани задавали тон. Уявимо собі, що під кінець Першої світової війни німці визнали б незалежність Польщі на території російської окупації i, навіть, схилилися підтримати прагнення такої Польщі на Сході, але взамін на тривалу відмову від Великопольщі. Що б подумали мешканці Великопольщі про таку домовленість і про співвітчизників, які її уклали?

По третє, польсько-українські взаємини завжди мали соціяльне забарвлення. Соціяльні відносини грунтувалися на тому, що суспільна еліта була польською, а звичайний нарід - українським. У XIX ст. так склалися соціяльні відносини в Галичині. Подібну елітарну роль відігравали угорці на території Корони Святого Стефана, що значно перевищувала етнічні межі угорської нації, а в державах Корони Святого Вацлава - німці, які панували над чехами. У всіх цих випадках це породило спокусу проводити “консервативну модернізацію”. В іï межах соціяльна перевага пануючої нації мала вживатися як засіб асиміляції. Подібно мислили діячі Гакати про національні відносини на німецькому Сході. Всі такого типу візії були ілюзіями. Консервативна модернізація ніде не мала успіху, призвела, натомість, до складних національних конфліктів. Про їх інтенсивність і потужність свідчило те, що боролися на теренах, де обидві сторони були переконані, що є "у себе"15.

\footnotetext{
${ }^{14}$ Щодо ставлення галицьких українців до Петлюри нині дискутують українські історики: Володимир Сергійчук, Симон Петлюра. (Київ: Україна, 2004); Олександр Рубльов, Олександр Реєнт, Украӥнські визвольні змагання 1917-1921. (Київ: Альтернативи, 1999); Wołodymyr. Krawczenko, Najnowsze dzieje Polski w historiografii ukraińskiej, (in) Widziane z zewnatrz, pod red. M. Baczkowskiego i in., (Warszawa: DiG, 2011), 155-156.

${ }^{15}$ Суспільний контекст взаємин на східних землях даньої Речі Посполитої розумів британський прем’єр Девід Ллойд-Джодж. Хоч він і був прихильником розпаду Росії по національних швах, що зближувало його з Пілсудським, але в той же час виступив проти федеральних планів,
} 
ISSN 2078-6077. Наукові зошити історичного факультету Львівського університету. 2020. Випуск 21. Proceedings of History Faculty of Lviv University. 2020. Issue 21.

Настанову Пілсудського від 1919 р., який “поставив засаду, що українці в цій частині під польським пануванням не можуть мати гірших умов від тих, які мали під управлінням Австріі”' ${ }^{\prime}$, за таких обставин було складно виконати. Не вдалося реалізувати концепції незалежної, приязної до Польщі України за Збручем. Не змогли також розв'язати справу автономії Східної Галичини, хоч би в таких межах як вона функціонувала у Сілезії. Всупереч початковим намірам Пілсудського пізніша практика польської політики щодо українців йшла в ногу 3 націоналістичними концепціями. Земельна реформа проводилася так, щоб зменшити користі, які від неї могли отримати українці. Головним елементом такої політики було форсування військового осадництва, зовсім не вмотивованого в перенаселеному селі. Формальна двомовність шкіл фактичного віддавала перевагу польській мові. Не сповнилися сподівання українців щодо створення університету у Львові. Підживлювалися сепаратистські рухи щодо української нації, підтримуючи окремішність гуцулів, бойків чи лемків 3 одного боку, а волинян з іншого. На шкоду греко-католицької церкви підтримували православ'я. На порозі 1930-х рр. в межах загострення диктатури в цілій державі проведено брутальну пацифікацію. За таких обставин, навіть відомості зі східного кордону про Великий Голод не змогли переконати більшість українців, що залишитися в кордонах Польщі є “меншим злом” у порівнянні з радянською Україною. Були українські політики, які лояльно ставилися до польської держави, але вони користувалися малою підтримкою суспільства.

Поляки не повинні мати проблеми зрозуміти реакцію народу, який програв повстання і опинився під окупацією. В цій ситуації всі форми спротиву разом 3 продовженням боротьби в конспіративних умовах варто вважати справедливими.

\section{Висновки}

Німці й українці не пов'язували з утворенням Другої Речі Посполитої жодних сподівань. Вони опинилися в цій державі проти своєї волі, внаслідок програних воєн. Трактували свій статус як неприйнятний, щонайбільше перехідний. Не змінювала цей стан справ державна лояльність, прийнята, як правило, лише 3 практичних поглядів. Націотворчі процеси в цій частині Европи були вже настільки розвинуті, що важко було сподіватися на успіх політики асиміляції. 3 цього погляду шанси на довготривалість Другої Речі Посполитої в таких територіяльних і національних межах не були великі.

Під час Першої світової війни в Европі переміг принцип самовизначення націй, що в результаті мало призвести до створення національних держав. Були у цьому винятки. Повстали дві (якщо не враховувати СРСР) багатонаціональні федерації:

побудованих на тлі польських прагнень. Він вважав, що примусові починання поляків неминуче визначають їхню соціально-консервативну природу. Для нас це було прикро, але в такому розумінні було раціональне ядро. Див.: Tadeusz Piszczkowski, Anglia a Polska 1914-1939 w świetle dokumentów brytyjskich, (Londyn: Oficyna Poetów i Malarzy, 1973), 71-216.

${ }^{16}$ Цит. за: Jerzy Tomaszewski, Rzeczpospolita wielu narodów, (Warszawa: Czytelnik, 1985), 87. 
Чехословаччина і Королівство сербів, хорватів і словенців чи Югославія. На довшу мету вони також не виявилися тривалими. Друга Річ Посполита, отримуючи незалежність в кордонах більших за польську етнічну територію, була винятковим випадком. Була спроба організувати іï на принципах федерації, але досягнути цієї мети не вдалося. На це були свої причини. По перше, київський похід 1920 р. завершився поразкою. По друге, в польському суспільстві ідея федерації не знайшла достатнього розуміння і підтримки. Цей другий чинник 3 часом виявився визначальний. В результаті збудовано а́агатонаціональну державу, яка у своїй внутрішній політиці спиралася лише на інтереси польської нації. Крім того, в Другій Речі Посполитій, на відміну від двох згаданих федерацій, національні бар'єри покривалися з суспільними поділами. І в Чехословаччині, і в Югославії домінуючі нації: чехи і серби звинувачувалися в гегемонії. Однак, чехи не були панівною верствою в Словаччині, коли ці функції виконували угорці. Подібно серби не панували в Словенії, Хорватії чи в Боснії і Герцеговині. Там відповідно домінували німці, угорці і мусульмани. Тим часом, поляки виконували таку роль в Східній Галичині. Це зумовило нестабільність системи, створеної в міжвоєнний період.

Поляки часто ідеалізують Другу Річ Посполиту. Зауважують, що хоч і мала свої гріхи на совісті, але наприкінці героїчно впала в слушній справі. Проте, такий кінець не може виправдати попередні провини, а навпаки породжує нові. До такої ідеалізації міжвоєнної Польщі спричинилася також пропаганда Польської Народної Республіки, яка протягом довгого часу форсувала “чорну” легенду Другої Речі Посполитої. Це викликало реакцію у вигляді безкритичної ідеалізації, з якої моє покоління лише зараз має шанси визволитися. Можна ці процеси раціонально з'ясувати і пояснити. Проте, доводять вони до висновку, вірогідність якого варто перевірити. Поляки, на загал, вважають, що Друга Річ Посполита була державою успіху, яка була на доброму шляху розвитку. Війна і напад ворогів перервали цю траєкторію успіху, на кінці якої знаходилася стабільна і новочасна держава. Цей образ видається наївною ілюзією. Національна напруга унеможливила б такий розвиток. Коли б шукати аналогій до польсько-українських відносин без втручання чужоземних сил, то бачимо подібність з британськоірландськими відносинами. 3 неминучим звільненням народу, позбавленого незалежности і з неминучим, кривавим конфліктом там, де дві сторони почувалися "у себе". За такого розуміння минуле Львова схоже на історію Ольстеру. 
ISSN 2078-6077. Наукові зошити історичного факультету Львівського університету. 2020. Випуск 21. Proceedings of History Faculty of Lviv University. 2020. Issue 21.

\title{
THE ATTITUDE OF GERMANS AND UKRAINIANS TO THE INDEPENDENCE OF POLAND
}

\author{
Wojciech MORAWSKI \\ Warsaw School of Economics, \\ Department of Economic and Social History \\ al. Niepodległości 162, 02-554 Warsaw, Poland \\ e-mail:
}

The subject of the attitude of Germans and Ukrainians towards the Second Polish Republic should be taken into account in connection with the so-called Historical policy, which in Poland clearly found itself in a dead end. An effective historical policy should lead to the fact that our historical narrative is understood and recognized as equal by other subjects of history. This state of affairs is possible only on the basis of reciprocity, which can not be obtained without empathy. To paraphrase the famous words of the Polish bishops of 1965 targeted to the Germans, this assumption can be summed up with the slogan: "we try to understand and ask for understanding.î With the obvious caveat that "to understandî does not necessarily mean "agreeî. It does not have to mean "forgiveî. Certainly, however, it is better to understand something than not understand it. For these reasons, it is worth accepting the multiplicity of narratives, and watching Polish affairs from the point of view of national minorities living in our country can only broaden our horizons.

The Second Republic was a multinational state, which, however, did not decide on the federal system, but rather sought, in a more or less veiled way, to assimilate minorities. In retrospect, such a goal should be considered completely unrealistic. Relations with two minorities: Germany and Ukrainians played a key role. Both nations found themselves in Poland after losing wars and, at best, treated their situations as a temporary necessary evil. The chances of political stabilization of such a formatted state were minimal.

In the Poles' awareness, the Second Polish Republic was idealized. She had her sins on her conscience, but ultimately died heroically in a just cause. This end was not conducive to judging earlier wines. On the contrary, he promoted their wholesale settlement. An important role was also played by propaganda of the PRL, which for a long time pushed the black legend of interwar Poland. Her intrusiveness evoked a reaction in the form of uncritical idealization, which my generation is now trying to free.

Poles generally believe that the Second Polish Republic was a country of success that was on the right path of development. The war interrupted this trajectory of success, at the end of which a modern and powerful state was to be created. Such a vision seems like a naive illusion. Nationalist tensions would make such development impossible. If we are looking for an analogy to the further development of Polish-Ukrainian relations without the interference of foreign forces, the British-Irish relations seem to be a proper comparison. With the inevitable liberation of a nation deprived of independence and the inevitable bloody conflict in a territory where both sides felt ,at home". In this situation, the future of Lviv would remind what happened in Ulster.

Keywords: Germany, Ukrainians, the Second Republic of Poland, assimilation

\section{REFERENCES}

Braudel F. Historia i trwanie. (Warszawa: Czytelnik, 1999).

Dmowski R. Myśli nowoczesnego Polaka. (Gdańsk: Młoda Polska, 1981).

Grünberg K. Niemcy $i$ ich organizacje $w$ Polsce międzywojennej. (Warszawa: Wiedza

Powszechna, 1970).

Holzer J. Mozaika polityczna Drugiej Rzeczypospolitej. (Warszawa: Książka i Wiedza, 1974). 
Krawczenko W. Najnowsze dzieje Polski w historiografii ukraińskiej, (in) Widziane z zewnatrz, pod red. M. Baczkowskiego i in., (Warszawa: DiG, 2011).

Kuchabsky V. Western Ukraine in Conflikt with Poland and Bolshevism 1918-1923. (Edmonton-Toronto: Canadian Institute of Ukrainian Studies Press, 2009).

Magosci P. R. Historia Ukrainy. Ziemie i ludzie. (Kraków: Księgarnia Akademicka, 2017).

Mosse G. L. Kryzys ideologii niemieckiej. Rodowód intelektualny Trzeciej Rzeszy. (Warszawa: Czytelnik, 1972).

Piszczkowski T. Anglia a Polska 1914-1939 w świetle dokumentów brytyjskich, (Londyn: Oficyna Poetów i Malarzy, 1973).

Tomaszewski J. Ojczyzna nie tylko Polaków. (Warszawa: Młodzieżowa Agencja Wydawnicza, 1985).

Tomaszewski J. Rzeczpospolita wielu narodów, (Warszawa: Czytelnik, 1985).

Zaleski W. J. Międzynarodowa ochrona mniejszości narodowych. (Warszawa: St. Niemiry Syn i S-ka, 1932).

Кучабський В. Західна Украӥна у боротьбі з Польщею та більшовизмом у 1918-1923 роках. (Львів: Дослідно-видавничий центр Наукового товариства ім. Шевченка, 2015).

Магочій П.-Р. Ілюстрована історія України. (Київ: Критика, 2012).

Рубльов О., Реєнт О. Украӥнські визвольні змагання 1917-1921. (Київ: Альтернативи, 1999).

Сергійчук В., Симон Петлюра. (Київ: Україна, 2004). 
буде ефективною, коли нашу історичну нарацію розумітимуть і визнаватимуть рівноправною інші суб'єкти історії. Рівноправною, але не єдиною. Таке визнання можливе лише на засаді взаємности, а іiї неможливо досягти без емпатії. Перефразовуючи відомі слова єпископів 1965 р., девізом таких завдань може бути: “стараємося зрозуміти і просимо розуміння". Тут мушу застерегти, що “зрозуміти” не завжди означає “визнати правдивість”. Це також не обов'язково означає "пробачити". Однак ніхто мене не переконає, що краще не розуміти, ніж розуміти. 3 цих причин варто прийняти плюралізм нарації, а погляд на польські справи $з$ точки зору національних меншин, що мешкають у нашій країні, може лише розширити наші горизонти. Відкритість колись була стандартом, а тепер іiі необхідно боронити від націоналістичної нарації, яка виключає “чужі” елементи.

XIX століття було часом розвитку націотворчих процесів і зростання значущости національної свідомости. Це підкопувало багатонаціональні держави, що домінували в Центрально-Східній Европі. Коли в Західній Европі держави набули національного характеру ${ }^{2}$ ще в нові часи (якщо не раніше), то в нашій частині континенту довго домінували багатонаціональні монархії, колись створені в результаті завоювань чи династичних союзів. Більшість націй у цій частині Европи не мали власних держав. За таких обставин національна свідомість вибудовувалася, грунтуючись на етнічній спільності чи, передовсім, на спільній мові.

Поляки тут не були особливі. Після поділів Речі Посполитої польська національна свідомість розвивалася двома шляхами. Поляки в XIX ст. не мали своєї держави, але втратили їі відносно недавно. Пам'ять про форму цієї держави, в т. ч. й територіяльну, була настільки свіжа, що на неї могли покликатися. Зберігався державний, політичний патріотизм. Патріоти від часу національних повстань боролися за відбудову такої Польщі, яка колись існувала в кордонах 1772 р. Це означало воювати за відродження багатонаціональної держави, що помітно й у символіці повстань. Під час листопадового повстання вживано герб 3 двох частин, на якому був Орел і Погонь. Це була традиційна візія Речі Посполитої двох народів: поляків і литовців. У січневому повстанні використовували трикуспідальний щит з Орлом, Погоню й Архангелом Михаїлом (символом Руси). Тут бачимо візію Речі Посполитої трьох народів: поляків, литовців та українців. У будь-якому випадку Польщу не вважали етнічно однорідною державою. У 90-х роках XIX ст. національна демократія запропонувала етнічне розуміння нації. Ї̈і метою була Польща як мононаціональна держава. Не випадково ендеки були першим політичним рухом у Польщі після поділів, який відкидав ідею багатонаціональної держави․․ Це також означало

\footnotetext{
${ }^{2}$ Навіть Швайцарії з їі етнічним, в будь-якому разі мовним різноманіттям, вдалося витворити почуття національної ідентичности, яке грунтувалося на державному патріотизмі.

${ }^{3}$ Добре ілюструє оригінальність ендеків під цим кутом зору приклад з протилежного боку політичного спектру. Соціял-демократія Польського Королівства і Литви при всьому своєму небажанні незалежности, виявилася у виборі назви напрочуд консервативною - Соціял-демократія Обидвох Народів (як перед поділами).
} 
ISSN 2078-6077. Наукові зошити історичного факультету Львівського університету. 2020. Випуск 21. Proceedings of History Faculty of Lviv University. 2020. Issue 21.

відмовитися від традиційного територіяльного визначення чи кордонів 1772 p. Ендеки, на відміну від традиційних патріотів, головною вважали етнічну спільноту, а не політичну. Так вони змінили основні геополітичні параметри польського питання. Для польських патріотів найбільшим нещастям була втрата держави чи втрата незалежности. Саме тому для них головним ворогом була Росія. Вона відіграла провідну роль у поділах, бо Росія відібрала більшість території давньої Речі Посполитої зі столицею. На біду, можна було б уявити незалежну Польщу без Галичини чи пруської частини, але не без Варшави. Для націоналістів це виглядало інакше. Якщо головною цінністю став народ, а не держава, то втрата незалежности перестає бути найбільшим нещастям. Вона була лише втратою держави. Коли народ переживе цей виклик, то колись собі незалежність відшукає. Справжньою бідою була б денаціоналізація чи втрата національної свідомости. Нація, яка дозволить собі денаціоналізацію, перестає існувати. Націоналісти вірили, що це можливо. За такого підходу національну належність людини остаточно визначає іiї власна свідомість. Інакше кажучи, людина є тим, за кого себе вважає. Оскільки так, то можна ії переконати змінити своє бачення. Якщо переконаємо поляка, що він $є$, наприклад, німцем настільки успішно, що сам добровільно про це говоритиме, то від тієї хвилі буде німцем і неможливо з цим дискутувати.

Потрібно пам'ятати, що зміна національної свідомости може бути лише добровільним актом. Силою тут нічому не зарадиш. А оскільки так, то нація, яку асимілюють, мусить бути настільки привабливою, щоб було “варто” іiі денаціоналізувати. Інакше кажучи, мусить чимось вражати, а сама асиміляція повинна пов'язуватися із поступом, що відчутий суб'єктивно. 3 цього погляду різні національні культури не $є$ рівнозначні. Вони $€$ ієрархізовані щодо рівня привабливости. Одні більше придатні до денаціоналізації, інші - менше. Рух в протилежному напрямку є мало правдоподібний.

Дивлячись 3 цієї перспективи на країни, які поділили Польщу, ендеки наново оцінили їх можливості і визнали, що при всій своїй брутальності росіяни не $\epsilon$ небезпечними, бо зросійщити поляків їм не вдасться. Простіше кажучи, вважали російську культуру замало привабливою, щоб вона заімпонувала полякам. 3 німцями справа виглядала небезпечніше. Якщо німці будуть діяти мудро і не робитимуть багато помилок, то германізація поляків може їм вдатися. Саме тому, обираючи між німцями і росіянами, поляки повинні йти з росіянами, бо німці є найнебезпечнішою нацією серед тих, хто поділив Польщу. Зауважмо, що в цьому міркуванні було щось із поваги до німців й дещо із зневаги до росіян. Ефектом, однак, було посилення проросійської орієнтації.

Також варто звернути увагу, що подібні критерії, як при оцінці можливости денаціоналізації поляків, ендеки використали ідею шансу полонізувати національні меншини, які замешкували Польщу. Вірили в можливість полонізації литовців, білорусів та українців. При цьому національну свідомість українців вважали розвинутішою, ніж білорусів. Саме тому т. зв. лінія Дмовського чи пропонована 
під час мирних переговорів у Парижі в 1918 р. візія кордонів Польщі на півночі, на білоруському відтинку, була висунута на схід істотно далі, ніж на південному відтинку - українському.

Націоналістична формула національної свідомости, пристосована до польськонімецької конфронтації на Заході, виявилася абсолютно непридатною до відносин на Сході. Там (у будь-якому випадку, поки ситуація не сприймалася як придушення прагнень національних меншин, а лише як польсько-російське протистояння) потрібна була формула багатонаціональної держави, де б шанували ідентичність й свободу вибору. За такими принципами спробував будувати польську східну політику Юзеф Пілсудський, але прихильність до цього в польському суспільстві постійно зменшувалася. Про це свідчили падіння федеральної політики, поразка Центральної Литви, а пізніше ескалація польськоукраїнського конфлікту.

Друга Річ Посполита, чи, власне, відроджена Польща з'явилася з плутанини після Першої світової війни як багатонаціональна держава. Відомі суперечки істориків щодо неточности даних, які грунтуються на переписі людности від 1931 p. $^{4}$ Долучимо остаточні підрахунки Сжи Томашевського, які вважаємо виваженими і близькими до реальности. За ними, поляки становили $65 \%$ громадян Речі Посполитої, українці - 16\%, євреї - 10\%, білоруси - 6\%, німці $2 \%$, інші $-1 \%{ }^{5}$. Реальне значення взаємин 3 конкретними меншинами не відображало їхнього чисельного потенціялу й залежало радше від того, як ці відносини могли вплинути на довговічність держави. Зваживши на це, можна збудувати іншу ієрархію важливости. Польсько-єврейські відносини були важливі з огляду на їх вплив на зовнішню політику. Поступово зростало значення євреїв у формуванні образу Польщі у світі. Проте, не від них залежало виживання Другої Речі Посполитої. Тим паче, воно не залежало від ставлення до відродженої Польщі білорусів, росіян, татар чи литовців. Життєво важливими для Польщі були взаємини $з$ двома націями: німцями й українцями.

Можна стверджувати, що справи у взаєминах у трикутнику німці-полякиукраїнці визначали результат експерименту, за яким була створена багатонаціональна Друга Річ Посполита. Ризикнемо висунути тезу, що у польськонімецьких й польсько-українських взаєминах можна говорити про щось на зразок симетрії. Коли під кінець Першої світової війни за пунктами президента Вільсона право націй до самовизначення піднесли до ранги фундаменту міжнародних відносин, слідом за цим не прийшло визнання рівности націй. Навпаки, продовжував домінувати погляд, що деякі нації є важливіші від інших і мають виконати щодо них цивілізаційну місію. Порівняння формального прийняття націоналізму з толерантністю щодо їх ієрархії й оцінки створило сприятливий

\footnotetext{
${ }^{4}$ Див.: Jerzy Tomaszewski, Ojczyzna nie tylko Polaków. (Warszawa: Młodzieżowa Agencja Wydawnicza, 1985), s. 31-51.

${ }^{5}$ Ibidem, s. 50.
} 
ISSN 2078-6077. Наукові зошити історичного факультету Львівського університету. 2020. Випуск 21. Proceedings of History Faculty of Lviv University. 2020. Issue 21.

грунт для злих емоцій, які в результаті зробили версальський лад лише коротким епізодом між двома світовими війнами.

Міжвоєнна Польща була багатонаціональною державою, яка вирішила не мати федеративний устрій, а прагнула в більше чи менше завуальований спосіб асимілювати меншини. Мало це низку наслідків. Одним із найсерйозніших була корозія демократії. Збереження національного характеру багатонаціональної держави мало актуалізувати питання рівности громадян перед законом та легітимности демократичних механізмів. Драматично це дало про себе знати під час виборів 1922 р. й президентства Габриеля Нарутовича. Прив'язаність до демократичних механізмів обидвох політичних таборів Другої Речі Посполитої виявилася поверховою. Табір лівих незалежників, на який у 1926 р. політично опирався Юзеф Пілсудський, у часи Першої світової війни отримав досвід меншости, яка (на її власну думку) мала рацію проти думки більшости. Болючою травмою для того середовища стало вбивство президента Г. Нарутовича.

Ставлення Національної Демократії до демократії, написаної з малої літери, вимагає ретельнішого аналізу. Цей рух помістив слово “демократія” у своїй назві на сам кінець. Було воно для націонал-демократів важливе. Як вони розуміли це слово? Видається, що для ендеків “демократія” мала два визначення. По перше, воно відображало соціяльний егалітаризм у національній спільноті, відмову від будь-яких пережитків станових поділів. По друге, ендеки специфічно розуміли демократичні механізми. В “Думках сучасного поляка" читаємо: “Бути поляком - означає, що належиш до польської нації на всій ії території і за весь час іiї існування. Це означає, що відчуваєш свій тяглий зв' язок із цілою Польщею: і нинішньою (...), і минулою (...), i, врешті, майбутньою (...). Щодо сучасної Польщі людина відчуває обов'язок від свого імени, а до давнішої і майбутньої від імени свого покоління...” Від імени нації треба вести політику і почувати себе відповідальним перед нею. Якщо дослівно, а не риторично, трактувати таке формулювання, то це спричинить серйозні наслідки для устрою держави. За такого визначення нації покоління, що тепер живе, є лише випадковою меншістю і може повністю помилятися. Його думка не мусить бути обов'язкова для лідера, який відповідає перед спільнотою, яка розуміється широко і “знає краще"?.

Зваживши на історичний досвід, асиміляцію меншин варто визнати нереальним завданням. І німці, й українці опинилися в межах Польщі після того, як програли війни і трактували свій стан у кращому випадку як перехідне необхідне зло. При цьому німці вважали себе нацією, цивілізованішою від поляків,

\footnotetext{
${ }^{6}$ Roman Dmowski, Myśli nowoczesnego Polaka. (Gdańsk: Młoda Polska, 1981), 17-18.

${ }^{7}$ Обмеженням демократизму ендеків було також ексклюзивне розуміння нації, звуження іiі до римо-католицизму та сектантське виокремлення “Правильних Поляків”. Проти елементарної логіки, це посилювалося в моменти тріюмфу. Це сприяло успішності ендеків в опозиції, їх слабкости й нетривалости в урядуванні.
} 
і з презирством дивилися, наприклад, на польську економіку (Polnische Wirtschaft). Поляки своєю чергою подібно трактували українців (порівнюємо тут, очевидно, те, що відбувалося до 1939 р., а не перекручення Другої світової війни). Вони ставили під сумнів саме існування української нації й вірили в можливість полонізації українців. При цьому поляки вважали, що германізація їх самих не має шансу, а полонізація українців може відбутися. Саме тут на перший план вийшла національна мегаломанія, яка, як відомо, неминуче йде в ногу з прихованими комплексами

\section{Німці}

Ставлення німців до Другої Речі Посполитої було виразно вороже. В німецькій східній традиції зіткнулися дві політичні концепції. За однією, символом якої був Отто Бісмарк, східним сусідом Німеччини є Росія, з якою необхідно жити мирно й разом контролювати багато менших народів, що мешкають між німецькою й російською етнічними територіями. За другою, Росія є небезпечним сусідом, перед яким Німеччина може захиститися, підтримуючи прагнення націй, що жили між нею і Росією. Формування на цих землях незалежних держав звільнить Німеччину від російського сусідства. Такий спосіб мислення актуалізувався під час Першої світової війни в проєкті Центральної Европи (Mitteleuropa), на ньому також грунтувалася підтримка 3 боку Німеччини окремих польських прагнень й акту 5 листопада. Після капітуляції в 1918 р. на короткий час німці помірковано прихильно поставилися до незалежної Польщі. Німеччина швидко визнала польську державу й вела предметні переговори про евакуацію Польщею відділень Ober-Ost. Усе змінилося після великопольського повстання, і пізнішої участи Польщі як члена Антанти у мирних переговорах. Зауважмо, що територіяльні втрати Німеччини на користь Польщі були найбільші з усіх, які німці понесли в результаті версальського договору. Коли втрати на користь Франції та Бельгії були наслідком військової поразки в запеклих боях, то німці не мали враження, що їх перемогли поляки. На думку німців, поляки були невдячним народом, який швидко забув про роль німців в отриманні польської незалежности. Німці закидали полякам, що вони в час слабкости Німеччини приєдналися до іiі ворогів і максимально з цього скористалися. При цьому розміри польських територіяльних прагнень здивували німецьку громадську думку.

3 такого погляду ставлення до конкретних фрагментів нового кордону відрізнялося. Хоча німці у Великопольщі почувалися як у себе, однак розуміли, що в цій провінції мешкає польська більшість. Коли Польща отримає незалежність, а Німеччина в той самий час програє війну, то не вдасться утримати Великопольщу. Звичайно, думали про це без ентузіязму, але якась частина німецької громадської думки (очевидно, менша) була готова погодитися на таку розв'язку.

\footnotetext{
${ }^{8}$ Пропоную читачам прийняти такий спосіб міркування, який мені також дозволяє багато зрозуміти у взаєминах між цими трьома народами. Коли маю проблеми із розумінням, чому українці так, а не інакше реагують на польські кроки, то уявляю собі, як би поляки зреагували на аналогічні вчинки німців. Зазвичай, у цей момент усе мені стає зрозуміло.
} 
ISSN 2078-6077. Наукові зошити історичного факультету Львівського університету. 2020. Випуск 21. Proceedings of History Faculty of Lviv University. 2020. Issue 21.

Куди більш несподіваною стала поява проблеми польського Помор'я й доступу Польщі до моря. Німці менше розуміли право Польщі на ці землі. Разом 3 тим, таке вирішення мало набагато серйозніші практичні наслідки. Це означало перетнути територію Німеччини й відокремити анклав Східної Пруссії. Попри те, частина німецької громадської думки, звичайно істотно менша, ніж у випадку з Великопольщею, була схильна бачити цю проблему в категоріях відплати за поділи давньої Речі Посполитої.

Навіть небагато дружніх до Польщі німців не могли зрозуміти, чому з'явилася проблема Верхньої Сілезії. Цього неможливо було усвідомити у категоріях компенсації за кривди поділів. Сілезія не була анексована, бо вже раніше не належала до Польщі.

Усе це призвело до того, що жодна держава не пробуджувала в міжвоєнній Німеччині таких негативних емоцій, як Польща. Перед 1933 р. польсько-німецькі відносини були фатальні, що цілком відповідало очікуванням німецької громадської думки. Жоден уряд Ваймарської республіки не міг (навіть, якби хотів) покращити взаємини з Польщею. Уряд, який би щось таке зробив, з цієї причини би впав. Стан справ змінився після приходу до влади Гітлера.

Значення німців у Другій Речі Посполитій визначала не їх чисельність, але факт, що за ними стояла потуга сусідньої держави, що з будь-якого погляду (крім, тимчасово військового потенціялу) нависала над Польщею. Німці в Другій Речі Посполитій з огляду на їх минуле належали до трьох груп. Найчисленнішу першу групу становили ті, що раніше були громадянами Райху. Замешкували вони Великопольщу, Помор'я й частину сілезького воєводства. Для цієї групи зміна кордонів після Першої світової війни була найдраматичнішою. 3 панівної нації, яка жила у власній державі, вони стали національною меншиною. Що гірше, над ними урядувала нація, яку донедавна вони самі пригноблювали й намагалися германізувати. За таких обставин могли очікувати відповіді. Представники цієї групи були піддатливі до націоналістичних гасел й схильні трактувати відроджену Польщу як перехідний витвір.

До другої групи входили ті, хто перед 1914 р. жив в Польськім королівстві чи на Східних кресах. Для них зміна не була така драматична. Ще раніше вони були національною меншиною. Тепер змінилася лише держава, в якій їм довелося жити. Вони були краще пристосовані до нової ситуації й готові прийняти новий порядок.

Третю групу становили німці, які колись замешкували Галичину і Цєшинську Сілезію. Німці в Галичині швидко асимілювалися, і з ними не було проблем. Трохи інакше було з німцями в австрійській Сілезії. Вони, подібно до колишніх громадян Райху, відчували втрату позицій панівного народу й перетворення на національну меншину. Також були піддатливі до впливів національної ідеології, але радше у версії етнічній ${ }^{9}$, н не націоналістичній. Не випадково у 1930-х рр. бєльські німці найбільше піддалися національному соціялізмові.

\footnotetext{
9 В німецькій мові вже в XIX ст. функціонували два терміни, які визначали націю в дещо різному розумінні: Volk i Nation. Nation означав політичну націю - громадян Райху. Volk означав німців в етнічному значенні; тих, що розмовляють німецькою. На випадок з німцями тут була
} 
Німці в Польщі охоронялися т. зв. малим версальським договором ${ }^{10}$. Подібні угоди мусіли підписати всі держави, які отримали нові території в результаті конференції. Німці, які втратили землі, не мусили виконувати подібних зобов'язань. Це створило асиметрію, яку усунули лише після нормалізації польсько-німецьких відносин у 1930-х рр.

Німці, що опинилися в Польщі, перед зовнішніми викликами об'єднувалися в свої національні, позапартійні й кооперативні організації. Всередині цих інституцій існували різні погляди, однак це трактували як внутрішні справи, що не повинні демонструватися чужому й неприхильному оточенню. Так само в попередню епоху себе поводили поляки в Німеччині. 3 часом за територіяльним принципом сформувалися три німецькі національні організації ${ }^{11}$ : Німецька Асоціяція (Deutsche Vereinigung) на землях, які входили до складу Пруссії, Німецький Народний Союз (Deutscher Volksbund) - у Сілезії і Німецька Народна Асоціяція (Deutsche Volksverband) - на решті території Польщі. Організовано також партії не за національним принципом, а лише за ідеологічним: Німецька Католицька Народна Партія (Deutsche Katholische Volkspartei; з часом перетворена в Німецьку Християнську Народну Партію (Deutsche Christianische Volkspartei) та Німецька Соціялістична Робітнича Партія (Deutsche Sozialistische Arbeitrspartei), але вони менше значили.

Німці, крім охорони трактатом своїх прав як меншість, мали гарантоване право вибору - залишитися в Польщі. При цьому їх матеріяльні інтереси були цілком захищені. Питання залишитися і жити на постерунку чи переїхати до Німеччини було не однозначне. Опція репатріяції фактично означала згоду 3 територіяльними змінами. Тi, хто вирішив переїхати, послаблювали політичний потенціял й силу впливу тих, які залишалися. Подібну дилему переживали поляки на Східних кресах одразу ж після війни чи угорці в Семигороді після трактату в

істотна різниця. До Volk зараховували, наприклад, австрійців, більшість швайцарців, які не належали до Nation. Відповідно до цього німецький правий рух поділився на націоналістичний та етнічний. Після 1919 р. для німецьких націоналістів першочерговим завданням було відновити кордони 1914 р. У цьому плані німецька держава зазнала втрат й це варто виправити. Для німецького етнічного правого руху головним завданням було об'єднати усіх німців у єдиній державі. Лише відбудова Райху в кордонах 1914 р. цього не забезпечувала. Звідси й інші напрями експансії. Для німців першої групи реалізація націоналістичної програми означала реалізувати свої прагнення. Для бєльських німців цього було замало. Для їх з'єднання з Райхом була необхідна етнічна програма. Детальніше див.: George L. Mosse, Kryzys ideologii niemieckiej. Rodowód intelektualny Trzeciej Rzeszy. (Warszawa: Czytelnik, 1972).

${ }^{10}$ Договір між головними союзними державами і Польщею від 28 червня 1919 р., названий “малим версальським договором” накладав на Польщу обов'язок забезпечити права національних меншин. Див.: Por. Władysław Józef Zaleski, Międzynarodowa ochrona mniejszości narodowych. (Warszawa: St. Niemiry Syn i S-ka, 1932).

${ }^{11}$ Про німецькі політичні партії в Польщі див.: Jerzy Holzer, Mozaika polityczna Drugiej Rzeczypospolitej. (Warszawa: Książka i Wiedza, 1974), 274-284, 580-594; Karol Grünberg, Niemcy i ich organizacje w Polsce mi'dzywojennej. (Warszawa: Wiedza Powszechna, 1970). 
ISSN 2078-6077. Наукові зошити історичного факультету Львівського університету. 2020. Випуск 21. Proceedings of History Faculty of Lviv University. 2020. Issue 21.

Тріаноні. У результаті число німців у міжвоєнній Польщі зменшилося від майже 1 млн. в 1921 р. до 0,7 млн. в 1931 р. У специфічній соціяльній структурі німців у Польщі, де найбільше було великої земельної власности, дражливим питанням стала земельна реформа. Після 1925 р. існувала спокуса, щоб примусовим “допарцелюванням" польська держава особливо вдарила по німецьких маєтках. Таку небезпеку помітила Ліга Націй і пильнувала за цією справою.

Для німців стати національною меншиною в краю, де вони панували, було неприйнятним. Польська влада могла сподіватися на мінімальну (і то не завжди) державну лояльність. Шанс на неї тимчасово зріс після укладення пакту про ненапад у 1934 р., але це був максимум того, чого можна було успішно вимагати від німців. Пам'ятаймо також, що німецькі і господарські (наприклад, розбудована кооперація), і культурні (наприклад, шкільництво) організації отримували майже необмежені фінанси від німецької держави. Згода німецької меншини зі своїм статусом в Польщі не могла довго тривати за умов наростання скрізь націоналізму.

\section{Українці}

Українці опинились у Другій Речі Посполитій після програного національного повстання ${ }^{12}$ й 3 почуттям, що їх країну окуповано. Поляки дотепер так визначають стан справ у Східній Галичині. Тоді ж вважали всю Галичину за свій край і частину давньої Речі Посполитої, яку окупувала Австрія. Були переконані, що оволодіння цілою Галичиною було інтегральною частиною акту історичної справедливости, виправленням кривди поділів. Очевидно, поляки розуміли, що Галичина $є$ етнічно різна, але були переконані, що існують реальні шанси полонізувати українців. Це була дуже небезпечна і наївна ілюзія, однак настільки поширена, що ії варто проаналізувати. I тому:

По-перше, поляки вважали, що здобувши незалежность вони повернуть усі історичні можливості, які мала давня Річ Посполита і які змарнували в результаті власних політичних помилок. Річ Посполита в XVI і в першій половині XVII ст. мала (хоч про це можна дискутувати) шанс на створення понадетнічної $\mathrm{i}$ понадрелігійної політичної спільноти у вигляді “політичної нації”. Проте через істотні політичні помилки, про які тут не варто детально вести мову, вона ті шанси змарнувала. Починаючи щонайменше від 1648 р. ті можливості вже відійшли у минуле. Шанси побудувати “державницьку” національну свідомість, засновану на почутті політичної спільноти, існували в конкретний час ${ }^{13}$. Оскільки

\footnotetext{
${ }^{12}$ Історію конфлікту з українського погляду див.: Василь Кучабський, Західна Україна у боротьбі з Польщею та більшовизмом у 1918-1923 роках. (Львів: Дослідно-видавничий центр Наукового товариства ім. Шевченка, 2015); Павло-Роберт Магочій, Ілюстрована історія України. (Київ: Критика, 2012); Vasyl Kuchabsky, Western Ukraine in Conflikt with Poland and Bolshevism 1918-1923. (Edmonton-Toronto: Canadian Institute of Ukrainian Studies Press, 2009); Paul Robert Magosci, Historia Ukrainy. Ziemie i ludzie. (Kraków: Księgarnia Akademicka, 2017), 697 and next.

${ }_{13}$ Таким робом в певний час вдалося створити французьку націю. Чи вдалося створити британську чи іспанську націю, то в світлі нинішніх подій, дуже дискусійно.
} 
вже змарновані, то марно сподіватися їх повернути. Після поділів Польщі розвинулася українська національна свідомість і це був уже процес незворотний. Вже не було жодних можливостей його перезавантажити. Ендеки собі вигадали, що $€$ шанси полонізувати слов'янські національні меншини, накидаючи таке мислення більшості поляків. Звідси тенденція заперечити українську національну ідентичність і термін “етнографічний матеріял”, що вживався до слов”янських національних меншин.

По-друге, поляки спрощено дивилися на події 1918-1921рр. Так, воювали з українцями за Східну Галичину, але пізніше був союз із Петлюрою, київська експедиція, братерство зброї і, насамкінець, зворушливе вибачення, з яким Юзеф Пілсудський звернувся до українців. Саме тому баланс взаємин не $є$ однозначно негативний і можливі різноманітні компроміси. Слабкість такого розуміння полягала, однак, у незнанні внутрішніх розбіжностей в українській нації. Воно не враховувало, що в 1918-1919 pр. поляки воювали з галицькими українцями, а союз і братерство зброї мали з наддніпрянцями. Для галицьких українців досвід Петлюри і київська експедиція були чужими. Що гірше, вони мали право закидати Петлюрі те, що погодився залишити їх по польськім боці кордону, а це вважали зрадою ${ }^{14}$. А в кордонах Другої Речі Посполитої опинилися власне галицькі українці. Також там замешкували і волиняни, але галичани задавали тон. Уявімо собі, що під кінець Першої світової війни німці визнали б незалежність Польщі на території російської окупації і навіть схилилися підтримати прагнення такої Польщі на Сході, але взамін на тривалу відмову від Великопольщі. Що б подумали мешканці Великопольщі про таку домовленість і про співвітчизників, які її уклали?

По-третє, польсько-українські взаємини завжди мали соціяльне забарвлення. Соціяльні відносини грунтувалися на тому, що суспільна еліта була польською, а звичайний нарід - українським. У XIX ст. так склалися соціяльні відносини в Галичині. Подібну елітарну роль відігравали угорці на території Корони Святого Стефана, що значно перевищувала етнічні межі угорської нації, а в державах Корони Святого Вацлава - німці, які панували над чехами. У всіх цих випадках це породило спокусу проводити “консервативну модернізацію”. В іï межах соціяльна перевага панівної нації мала вживатися як засіб асиміляції. Подібно мислили діячі Гакати про національні відносини на німецькому Сході. Усі такого типу візії були ілюзіями. Консервативна модернізація ніде не мала успіху, призвела натомість до складних національних конфліктів. Про їх інтенсивність і потужність свідчило те, що боролися на теренах, де обидві сторони були переконані, що є "у себе"15.

\footnotetext{
${ }^{14}$ Щодо ставлення галицьких українців до Петлюри нині дискутують українські історики: Володимир Сергійчук, Симон Петлюра. (Київ: Україна, 2004); Олександр Рубльов, Олександр Реєнт, Украӥнські визвольні змагання 1917-1921. (Київ: Альтернативи, 1999); Wołodymyr. Krawczenko, Najnowsze dzieje Polski w historiografii ukraińskiej, (in) Widziane z zewnątrz, pod red. M. Baczkowskiego i in., (Warszawa: DiG, 2011), 155-156.

${ }^{15}$ Суспільний контекст взаємин на східних землях даньої Речі Посполитої розумів британський прем'єр Девід Ллойд-Джодж. Хоч він і був прихильником розпаду Росії по національних швах, що зближувало його з Пілсудським, але в той самий час виступив проти федеральних планів,
} 
ISSN 2078-6077. Наукові зошити історичного факультету Львівського університету. 2020. Випуск 21. Proceedings of History Faculty of Lviv University. 2020. Issue 21.

Настанову Пілсудського від 1919 р., який “поставив засаду, що українці в цій частині під польським пануванням не можуть мати гірших умов від тих, які мали під управлінням Австріі”' ${ }^{\prime}$, за таких обставин було складно виконати. Не вдалося реалізувати концепції незалежної, приязної до Польщі України за Збручем. Не змогли також розв'язати справу автономії Східної Галичини, хоч би в таких межах як вона функціювала в Сілезії. Усупереч початковим намірам Пілсудського пізніша практика польської політики щодо українців ішла в ногу 3 націоналістичними концепціями. Земельна реформа проводилася так, щоб зменшити користь, яку від неї могли б отримати українці. Головним елементом такої політики було форсування військового осадництва, зовсім не вмотивованого в перенаселеному селі. Формальна двомовність шкіл фактичного віддавала перевагу польській мові. Не сповнилися сподівання українців щодо створення університету у Львові. Щодо української нації підживлювалися сепаратистські рухи, підтримували окремішність гуцулів, бойків чи лемків 3 одного боку, а волинян 3 іншого. На шкоду греко-католицької церкви підтримувалося православ'я. На порозі 1930-х рр. у межах загострення диктатури в цілій державі проведено брутальну пацифікацію. За таких обставин навіть відомості зі східного кордону про Великий Голод не змогли переконати більшість українців, що залишитися в кордонах Польщі є “меншим злом” порівняно з радянською Україною. Були українські політики, які лояльно ставилися до польської держави, але вони мали мізерну підтримку суспільства.

Поляки повинні постаратися зрозуміти реакцію народу, який програв війну й опинився під окупацією. У цій ситуації всі форми спротиву разом з продовженням боротьби в конспіративних умовах варто вважати справедливими.

\section{Висновки}

Німці й українці не пов'язували з утворенням Другої Речі Посполитої жодних сподівань. Вони опинилися в цій державі проти своєї волі, унаслідок програних воєн. Трактували свій статус як неприйнятний, щонайбільше перехідний. Не змінювала цей стан справ державна лояльність, прийнята, як правило, лише 3 практичних поглядів. Націотворчі процеси в цій частині Европи були вже настільки розвинуті, що важко було сподіватися на успіх політики асиміляції. 3 цього погляду шанси на довготривалість Другої Речі Посполитої в таких територіяльних і національних межах не були великі.

Під час Першої світової війни в Европі переміг принцип самовизначення націй, що в результаті мало призвести до створення національних держав. Були у цьому винятки. Постали дві (якщо не враховувати СРСР) багатонаціональні федерації:

побудованих на тлі польських прагнень. Він вважав, що примусові починання поляків неминуче визначають їхню соціяльно-консервативну природу. Для нас це виглядало прикро, але в такому розумінні було раціональне ядро. Див.: Tadeusz Piszczkowski, Anglia a Polska 1914-1939 w świetle dokumentów brytyjskich, (Londyn: Oficyna Poetów i Malarzy, 1973), 71-216. 
Чехо-Словаччина і Королівство сербів, хорватів і словенців або Югославія. На довшу перспективу вони також не виявилися тривалими. Друга Річ Посполита, отримуючи незалежність у кордонах, більших за польську етнічну територію, була винятковим випадком. Була спроба організувати іiї на принципах федерації, але досягнути цієї мети не вдалося. На це були свої причини. По-перше, київський похід 1920 р. завершився поразкою. По-друге, в польському суспільстві ідея федерації не знайшла достатнього розуміння і підтримки. Цей другий чинник 3 часом виявився визначальний. У результаті збудовано багатонаціональну державу, яка у своїй внутрішній політиці спиралася лише на інтереси польської нації. Крім того, у Другій Речі Посполитій, на відміну від двох згаданих федерацій, національні бар'єри покривалися з суспільними поділами. І в Чехо-Словаччині, i в Югославії домінантні нації - чехи і серби - звинувачувалися в гегемонії. Однак, чехи не були панівною верствою в Словаччині, коли ці функції виконували угорці. Подібно серби не панували в Словенії, Хорватії чи в Боснії і Герцеговині. Там, відповідно, домінували німці, угорці й мусульмани. Тим часом, поляки виконували таку роль у Східній Галичині. Це зумовило нестабільність системи, створеної в міжвоєнний період.

Поляки часто ідеалізують Другу Річ Посполиту. Зауважують, що хоч і мала свої гріхи на совісті, але наприкінці героїчно впала у слушній справі. Проте, такий кінець не може виправдати попередні провини, а, навпаки, породжує нові. До такої ідеалізації міжвоєнної Польщі спричинилася також пропаганда Польської Народної Республіки, яка протягом довгого часу форсувала “чорну” легенду Другої Речі Посполитої. Це викликало реакцію у вигляді безкритичної ідеалізації, з якої моє покоління лише тепер має шанси визволитися. Можна ці процеси раціонально з'ясувати і пояснити. Проте доводять вони до висновку, вірогідність якого варто перевірити. Поляки, на загал, вважають, що Друга Річ Посполита стала державою успіху, яка стояла на доброму шляху розвитку. Війна і напад ворогів перервали цю тріюмфальну траєкторію, на кінці якої вимальовувалася стабільна новочасна держава. Цей образ видається наївною ілюзією. Національна напруга унеможливила б такий розвиток. Коли б шукати аналогій до польськоукраїнських відносин без втручання чужоземних сил, то бачимо подібність із британсько-ірландськими відносинами. 3 неминучим звільненням народу, позбавленого незалежности, і з неминучим, кривавим конфліктом там, де дві сторони почувалися “у себе”. За такого розуміння минуле Львова схоже на історію Ольстера. 
ISSN 2078-6077. Наукові зошити історичного факультету Львівського університету. 2020. Випуск 21. Proceedings of History Faculty of Lviv University. 2020. Issue 21.

\title{
THE ATTITUDE OF GERMANS AND UKRAINIANS TO THE INDEPENDENCE OF POLAND
}

\author{
Wojciech MORAWSKI \\ Warsaw School of Economics, \\ Department of Economic and Social History \\ al. Niepodległości 162, 02-554 Warsaw, Poland
}

The subject of the attitude of Germans and Ukrainians towards the Second Polish Republic should be taken into account in connection with the so-called Historical policy, which in Poland clearly found itself in a dead end. An effective historical policy should lead to the fact that our historical narrative is understood and recognized as equal by other subjects of history. This state of affairs is possible only on the basis of reciprocity, which can not be obtained without empathy. To paraphrase the famous words of the Polish bishops of 1965 targeted to the Germans, this assumption can be summed up with the slogan: "we try to understand and ask for understanding". With the obvious caveat that "to understandî does not necessarily mean "agreeî. It does not have to mean "forgive". Certainly, however, it is better to understand something than not understand it. For these reasons, it is worth accepting the multiplicity of narratives, and watching Polish affairs from the point of view of national minorities living in our country can only broaden our horizons.

The Second Republic was a multinational state, which, however, did not decide on the federal system, but rather sought, in a more or less veiled way, to assimilate minorities. In retrospect, such a goal should be considered completely unrealistic. Relations with two minorities: Germany and Ukrainians played a key role. Both nations found themselves in Poland after losing wars and, at best, treated their situations as a temporary necessary evil. The chances of political stabilization of such a formatted state were minimal.

In the Poles' awareness, the Second Polish Republic was idealized. She had her sins on her conscience, but ultimately died heroically in a just cause. This end was not conducive to judging earlier wines. On the contrary, he promoted their wholesale settlement. An important role was also played by propaganda of the PRL, which for a long time pushed the black legend of interwar Poland. Her intrusiveness evoked a reaction in the form of uncritical idealization, which my generation is now trying to free.

Poles generally believe that the Second Polish Republic was a country of success that was on the right path of development. The war interrupted this trajectory of success, at the end of which a modern and powerful state was to be created. Such a vision seems like a naive illusion. Nationalist tensions would make such development impossible. If we are looking for an analogy to the further development of Polish-Ukrainian relations without the interference of foreign forces, the British-Irish relations seem to be a proper comparison. With the inevitable liberation of a nation deprived of independence and the inevitable bloody conflict in a territory where both sides felt ,at home”. In this situation, the future of Lviv would remind what happened in Ulster.

Keywords: Germany, Ukrainians, the Second Republic of Poland, assimilation

\section{REFERENCES}

Braudel F. Historia i trwanie. (Warszawa: Czytelnik, 1999).

Dmowski R. Myśli nowoczesnego Polaka. (Gdańsk: Młoda Polska, 1981).

Grünberg K. Niemcy i ich organizacje w Polsce międzywojennej. (Warszawa: Wiedza

Powszechna, 1970).

Holzer J. Mozaika polityczna Drugiej Rzeczypospolitej. (Warszawa: Książka i Wiedza, 1974). 
Krawczenko W. Najnowsze dzieje Polski w historiografii ukraińskiej, (in) Widziane z zewnatrz, pod red. M. Baczkowskiego i in., (Warszawa: DiG, 2011).

Kuchabsky V. Western Ukraine in Conflikt with Poland and Bolshevism 1918-1923. (Edmonton-Toronto: Canadian Institute of Ukrainian Studies Press, 2009).

Magosci P. R. Historia Ukrainy. Ziemie i ludzie. (Kraków: Księgarnia Akademicka, 2017).

Mosse G. L. Kryzys ideologii niemieckiej. Rodowód intelektualny Trzeciej Rzeszy. (Warszawa: Czytelnik, 1972).

Piszczkowski T. Anglia a Polska 1914-1939 w świetle dokumentów brytyjskich, (Londyn: Oficyna Poetów i Malarzy, 1973).

Tomaszewski J. Ojczyzna nie tylko Polaków. (Warszawa: Młodzieżowa Agencja Wydawnicza, 1985).

Tomaszewski J. Rzeczpospolita wielu narodów, (Warszawa: Czytelnik, 1985).

Zaleski W. J. Międzynarodowa ochrona mniejszości narodowych. (Warszawa: St. Niemiry Syn i S-ka, 1932).

Кучабський В. Західна Украӥна у боротьбі з Польщею та більшовизмом у 1918-1923 роках. (Львів: Дослідно-видавничий центр Наукового товариства ім. Шевченка, 2015).

Магочій П.-Р. Ілюстрована історія України. (Київ: Критика, 2012).

Рубльов О., Реєнт О. Українські визвольні змагання 1917-1921. (Київ: Альтернативи, 1999).

Сергійчук В., Симон Петлюра. (Київ: Україна, 2004).

3 польської мови переклав Роман Масик 